\title{
THE PECULIARITY OF INVESTMENT COOPERATION OF THE REPUBLIC OF KAZAKHSTAN WITH PEOPLE'S REPUBLIC OF CHINA
}

\author{
Ph.D. student Tleulina Aigerim \\ People's Republic of China, Hunan province, Xiangtan city, Hunan Technical University of science \\ and technology
}

DOI: https://doi.org/10.31435/rsglobal_ijite/30112019/6798

\begin{abstract}
ARTICLE INFO
Received 26 September 2019

Accepted 10 November 2019

Published 30 November 2019

\section{KEYWORDS}

investment cooperation, economic development, direct investments, the Belt and Road Initiative. ABSTRACT

Investment cooperation between Republic of Kazakhstan and People's Republic of China is, first of all, that, being mutually beneficial, it provides for different in nature economic results for the interacting parties. China, as a result of this cooperation, is pursuing a solution to the problem of maintaining sustainable economic development. For Republic of Kazakhstan, investment cooperation with People's Republic of China should contribute to further maintaining sustainable economic growth and modernizing the national economy in order to effectively participate in the system of world economic relations.

Since 2015, investment flows from China to Kazakhstan have shown positive dynamics, their average annual growth is $22 \%$. At the same time, the largest volume of FDI falls on 2018: $\$ 1.5$ billion - $37.6 \%$ more than in 2017 , and $78.6 \%$ more than in 2015. For the first half of 2019, the gross inflow of investments from China amounted to 362 million US dollars.

In the Republic of Kazakhstan from 2015 to 2019, Kazakh-Chinese projects are implemented for a total amount of $\$ 35$ billion. During this period, 10 enterprises were launched.
\end{abstract}

Citation: Tleulina Aigerim. (2019) The Peculiarity of Investment Cooperation of the Republic of Kazakhstan with People's Republic of China. International Journal of Innovative Technologies in Economy. 6(26). doi: 10.31435/rsglobal_ijite/30112019/6798

Copyright: (C) 2019 Tleulina Aigerim. This is an open-access article distributed under the terms of the Creative Commons Attribution License (CC BY). The use, distribution or reproduction in other forums is permitted, provided the original author(s) or licensor are credited and that the original publication in this journal is cited, in accordance with accepted academic practice. No use, distribution or reproduction is permitted which does not comply with these terms.

Introduction. The economic importance of the Republic of Kazakhstan for People's Republic of China is primarily due to the presence of natural resources in the region, the potential for their development and the need to form transport infrastructure in the Chinese direction to increase Chinese imports of goods and services. The importance of Kazakhstan is growing in connection with the implementation of the projects of the Asian-European transport corridor according to the Belt and Road Initiative. Today, China is one of the leading investors in the economy of Kazakhstan, along with countries such as the Netherlands, USA, Switzerland and Russian Federation.

The relations between the two countries over the past few years have been developing systematically, the Belt and Road Initiative directly contributes to the strengthening of partnership agreements.

The Belt and Road Initiative, within the framework of which over the past 5 years a number of major infrastructure projects have already been commissioned: the port of Lianyungang; Khorgos - East Gate dry port on the border with China; Aktau port on the Caspian Sea; the new railway corridor Kazakhstan - Turkmenistan - Iran, with a total length of about $900 \mathrm{~km}$, connecting the countries of Central Asia with the Persian Gulf and the port of Bender Abbas in southern Iran; and also the international transit corridor "Western Europe - Western China", part of which passes through the Republic of Kazakhstan. Along the "Path" with the participation of Chinese companies, more than 80 zones of trade and economic cooperation were established and more than 200 thousand jobs were created.

Since 2015, investment flows from China to Kazakhstan have shown positive dynamics, their average annual growth is $22 \%$. At the same time, the largest volume of foreign direct investments (here and 
after - FDI) falls on 2018: $\$ 1.5$ billion - 37.6\% more than in 2017, and 78.6\% more than in 2015. For the first half of 2019, the gross inflow of investments from China amounted to 362 million US dollars (figure 1,2).

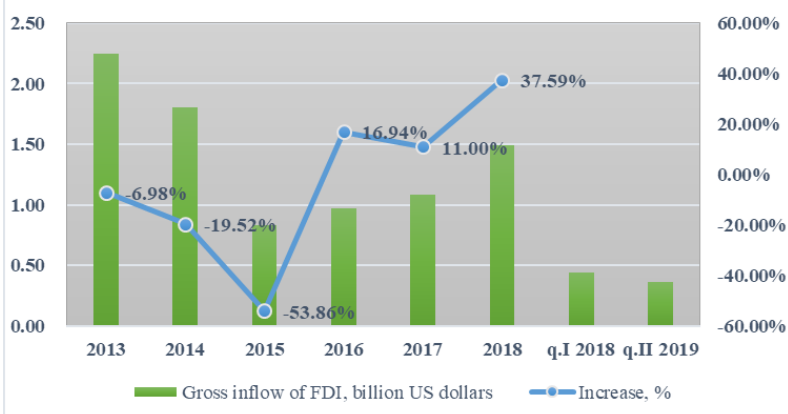

Fig. 1. The dynamics of Gross inflow of FDI, billion US dollars

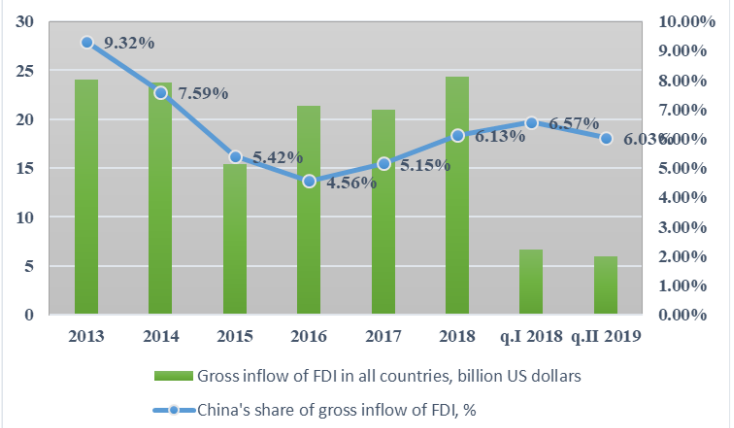

Fig. 2. China's share of gross inflow of FDI, billion US dollars

The liabilities of residents of the Republic of Kazakhstan to investors from People's Republic of China for the first quarter of 2019 reached \$ 15.3 billion. In the total structure of Kazakhstan's liabilities (220.3 billion US dollars), China's share was 6.9\% (figure 3,4). By types of economic activity, the largest volume is concentrated in the fields of transport and storage ( $\$ 5$ billion), mining ( $\$$ 2.6 billion), manufacturing ( $\$ 2.1$ billion), and construction ( $\$ 2$ billion) (figure 5).

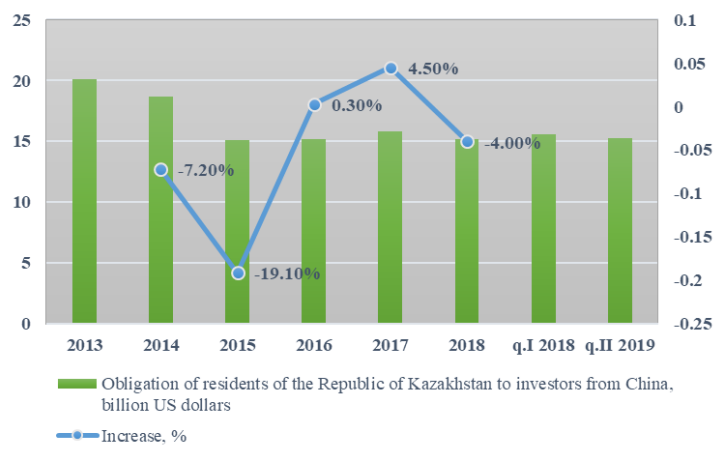

Fig. 3. The dynamics of obligation of residents of the Republic of Kazakhstan to investors from People's Republic of China

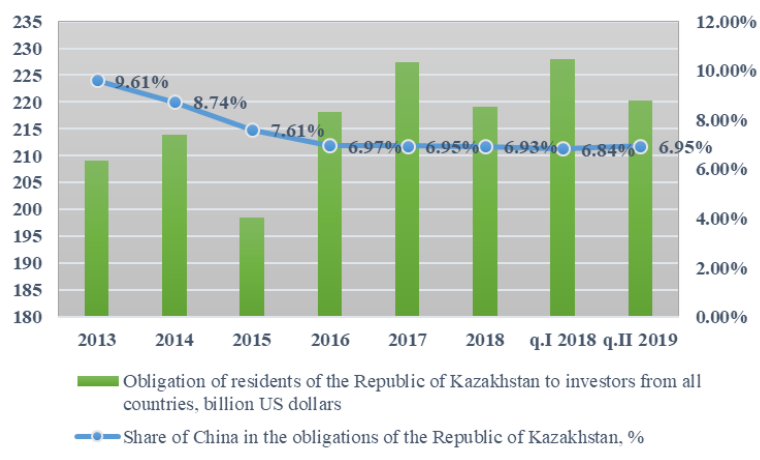

Fig. 4. China's share in the obligation of the Republic of Kazakhstan

Domestic investment flows into the Chinese economy in 2018 amounted to $\$ 41.8$ million, which is $8.2 \%$ more than in 2017 (\$38.6 million). China is among the top 10 countries in terms of gross outflow of direct investments of Kazakhstan - the share of investments was 3.2\%.

As of the end of July 2019, 2.5 thousand enterprises in China were registered in Kazakhstan, of which 1.1 thousand were operating. There are also three Chinese banks operating in the country: Altyn Bank, Bank of China Kazakhstan and ICBC (Commercial and Industrial Bank of China). According to the results of the half of the year, the assets of banks reached 886.2 billion tenge, or $3.5 \%$ of the total banking sector.

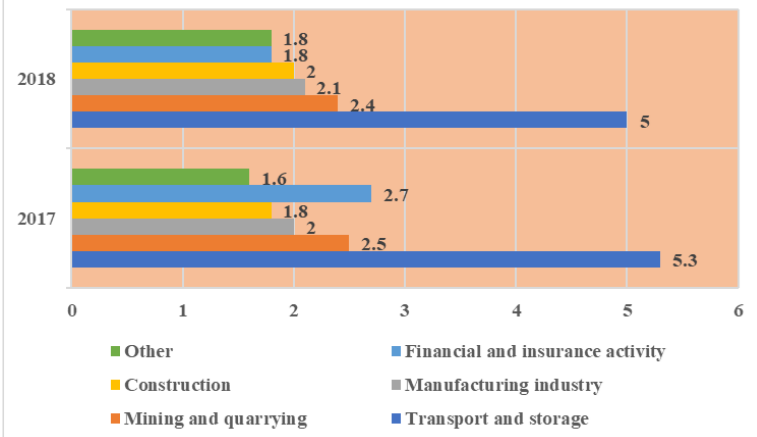

Fig. 5. Chinese investments by the type of activity

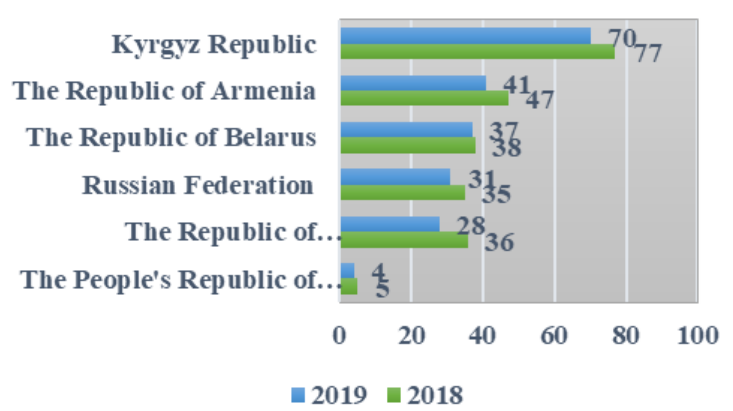

Fig. 6. Ease of doing business rating economic (place) in 2018-2019 
So, in the Republic of Kazakhstan from 2015 to 2019, Kazakh-Chinese projects are implemented for a total amount of $\$ 35$ billion. During this period, 10 enterprises were launched. The implementation of these projects will create about 20 thousand new permanent jobs. More detailed information on areas and volume of investments can be seen in Figure 7

The most significant projects are:

- Cement Production DanAke LLP, China Gezhouba Cement Co. Ltd. It was commissioned in December 2018. Investments totaled \$ 178 million; 226 jobs were created;

- Production of JAC cars by the methods of large-knot assembly (DKD / SKD) and smallknot assembly (CKD) together with the strategic partner of SaryarkaAvtoProm LLP and JAC Motors. It was put into operation in stages: stage I in 2015, stage II - in 2017. Investments amounted to 22 million US dollars, 350 jobs were created.

- Dry port on the territory of the FEZ (free economic zone) Khorgos-East Gate, "KTZE Khorgos Gateway" LLP, Lianyungang Port Holding Group Co. Ltd., COSCO Shipping Lines Co. Ltd. Investments totaled \$ 76 million.

13 projects are under implementation; in 2019, 3 projects are expected to be launched for a total of $\$ 350$ million.

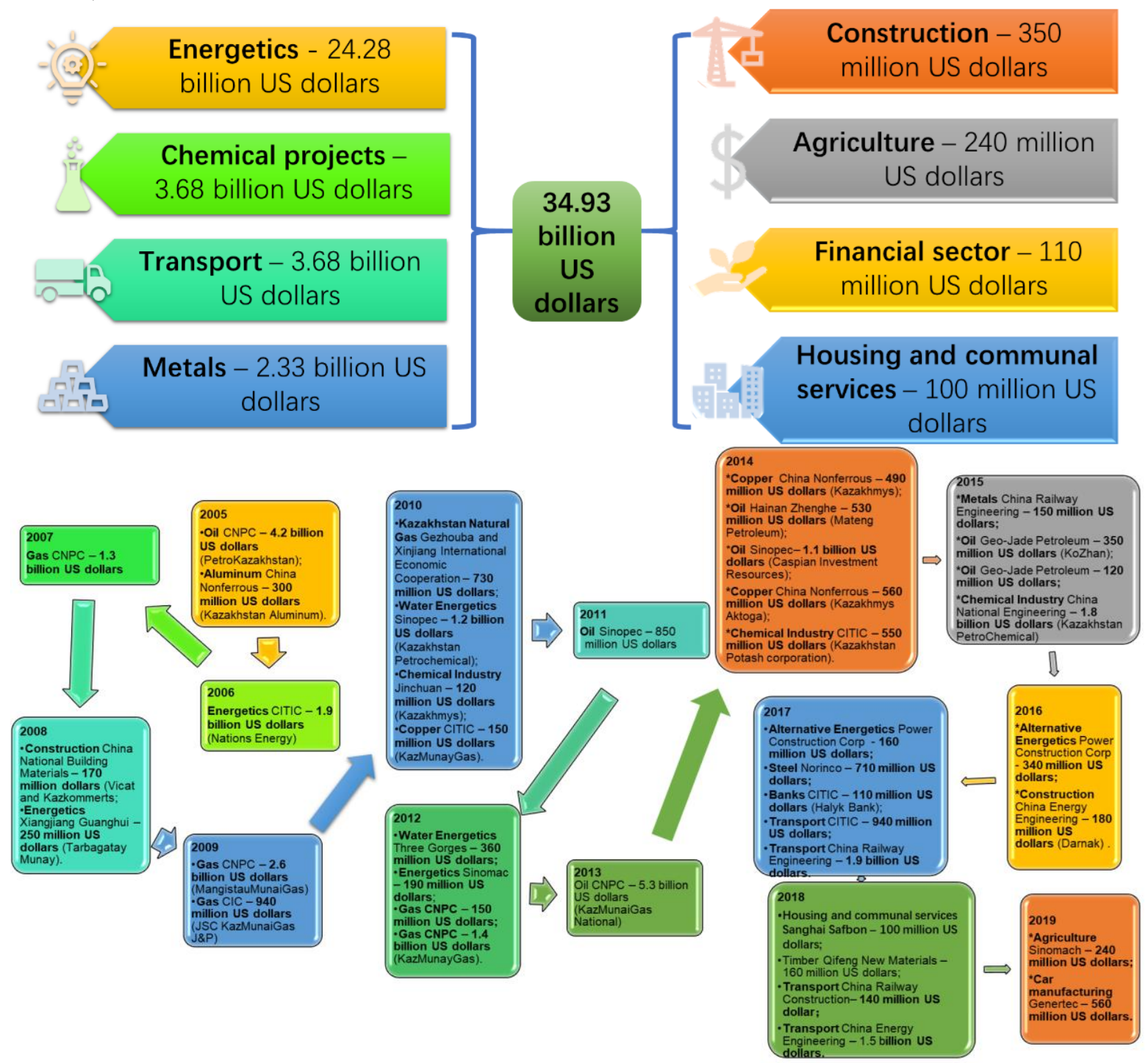

Fig. 7. Chinese investment to the Republic of Kazakhstan and cooperative projects from 2015-2019 years

Globalization of markets is also enhanced by the integration of the financial sector. Astana and its financial center are consolidating the investment activity of international investors. People's Republic of China is a vivid example of active participation in the development of the Republic of Kazakhstan capital market. In 2018, 5 memorandums and agreements were signed on the basis of a 
financial hub (in total 13 for 2016-2018), the main purpose of which is to develop a cross-border business to provide high-quality service and develop new financial services.

As shown by the World Bank's ease of doing business rating, this is a critical indicator evaluating the business orientation of countries around the world. According to the results of the rating for 2019, The Republic of Kazakhstan rose by 8 positions and took 28th place (in 2018 - 36th), becoming the best country in the region in doing business. The nearest neighbors from the EAEU are located in the corridor from 31st to 70th place. The People's Republic of China, in turn, took 4th place (in 2018 - 5th) (figure 7).

The peculiarity of investment cooperation between Republic of Kazakhstan and People's Republic of China is, first of all, that, being mutually beneficial, it provides for different in nature economic results for the interacting parties. China, as a result of this cooperation, is pursuing a solution to the problem of maintaining sustainable economic development. For Kazakhstan, investment cooperation with China should contribute to further maintaining sustainable economic growth and modernizing the national economy in order to effectively participate in the system of world economic relations. Thanks to the strategy put forward on the basis of the Belt and Road Initiative, the implementation of this cooperation has become real and possible. For China, which has enormous potential of the domestic market, innumerable labor resources, focus on solving problems of economic development, economic cooperation on the basis of the Belt and Road Initiative, it provides an opportunity to create conditions for expanding sales markets and further developing the country's export potential.

Summing up, it is worth noting that the implementation of the strategy on the basis of the Belt and Road Initiative contributes to the strengthening and bilaterally beneficial economic development of relations between Kazakhstan and China. The active participation of Kazakhstan in the international project for the implementation of the Belt and Road Initiative contributes to the intensification of external investment flows into the national economy.

The Republic Kazakhstan, as a region possessing the richest reserves of mineral resources, including oil, natural gas, iron ores, non-ferrous, rare, rare-earth, and precious metals, as well as a favorable territorial position for implementing the Belt and Road Initiative, provides People's Republic of China with tangible benefits.

\section{REFERENCES}

1. Electronic resource https://www.lsm.kz/investicii-kitaya

2. Electronic resource https://prodengi.kz/lenta/pochemu-kitaj-investiruet-v-kazahstan/

3. Electronic resource https://yandex.kz/turbo?text=https\%3A\%2F\%2Fwww.zakon.kz\%2F4947157-kitaystal-krupneyshim-investorom.html\&d=1

4. Electronic resource http://www.exclusive.kz/expertiza/biznes/116756/

5. Electronic resource https://nationalbank.kz/?docid=680\&switch=russian

6. Electronic resource http://ranking.kz/ru/a/rankings/v-2018-godu-pochti-polovina-stran-es-sokratilainvesticii-v-ekonomiku-kazahstana-obshee-snizhenie-valovogo-pritoka-pii-po-etim-stranam-sostavilo-122

7. Electronic resource https://www.imemo.ru/files/File/magazines/rossia_i_novay/2018_04/14.Dodonov.pdf 